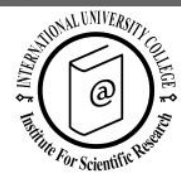

\title{
A molecular treatment of successful destinations: revisiting methodological individualism
}

\author{
Bernard Lew Shian Loong ${ }^{1 *}$
}

Received: 28/02/2012 Accepted:03/03/2012

\footnotetext{
${ }^{1}$ School of Hospitality, Tourism and Culinary Arts, Taylor's University, Malaysia; Bernard.lew@taylors.edu.my * Corresponding author
}

\begin{abstract}
With nanotechnology coming to the fore and molecular gastronomy entering the culinary arts, this paper proposes a molecular treatment of successful destinations. Yet it is a molecular metaphor that follows from methodological individualism as a methodological tenet. Post modern destination analysis has tended towards investigations at the micro-scale. Unlike the usual micro-macro dichotomy, that tends to be lop-sided, this molecular approach emphasizes the scalability of individual codified experiences to the global emergent properties of destinations. Computer simulations based on a spatial contagion model, suggests that successful destinations tend to be poised on the edge of chaos, maximizing molecular interchange and thus their ability to change and adapt. Informed by such findings the paper puts forward destination policy guidelines based on the consideration of two contrasting cases of heritage tourism: Venice and Singapore.
\end{abstract}

(C) 2012 International University College. All rights reserved

Keywords: Austrian economics, molecular tourism, methodological individualism, knowledge contagions, edge of chaos, destination development, Singapore, Venice.

Citation: Shian Loong, B. L. (2012) A molecular treatment of successful destinations: revisiting methodological individualism. European Journal of Tourism Research 5(2), pp. 106-117

\section{Introduction}

Somewhere in the 1930s, even before there was a Keynesian revolution, with the ensuing emphasis on economic planning and government intervention, the ideological divide was mainly between Austrian economics and Keynesian economics (Goodspeed, 2012). In this paper, I posit that this ideological struggle is still on-going and is recast as the tension between interventionist and bottom-up destination policies.
Though Austrian economics seems to have faded behind the scenes after the 1930s, it has recently experienced a flood of resurgent interest, brought about by the recognition that human psychology, knowledge and innovation lies at the vey core of our understanding of civil society (Ridley, 1998; Parker and Prechter, 2005). The Austrian tradition holds to its central premise that economic theories should be derived from human behavior axioms. This 
notion has been inherited and extended by a battery of behavioral-centric economic investigations. (Akerlof and Shiller, 2009; Harford, 2011; Kahneman, 2011). The growing realization of idiosyncratic demand has spawned corresponding efforts to uncover the "molecular structure" of brands (Lederer and Hill, 2001) and destination image (Ivanov, Illum and Liang, 2010).

With the tipping of the balance in academic inquiry towards knowledge and innovation once again, the idea of economic evolution and order stemming from individual experiences, and informational changes is once again in ascendance. A convincing case for a molecular approach has appeared in an article discussing the interface between science and the culinary arts:

\begin{abstract}
"The scientists involved in studying the molecular and physicochemical changes that occur in foods are usually characterized primarily by their rationality-their ability to systematically breakdown a complex system into simpler parts whose behavior can be understood within the prevailing scientific framework."
\end{abstract}

(van der Linden, McClements and Ubbink, 2008: 250)

This paper forwards the idea that destination research should once again scrutinize changes at the personal knowledge level (Polanyi, 1958), analogous to the attention given by chefs to molecular level changes in molecular gastronomy. In so doing it argues for the merits of methodological individualism (Schumpeter, 1908) in the conceptualization of destination success, over the usual macro, interventionbased approach in destination development. This means that there is much to be learned by revisiting methodological individualism, the central philosophical position in Austrian economics. Hence the molecular metaphor, which I shall at times refer to as: molecular tourism.

This paper attempts to outline the essence of a molecular perspective on tourism. Such a perspective would be buttressed by four major themes. The four major themes are:

- A bottom-up approach to destination competitiveness based on the precept known as methodological individualism.

- An emphasis on dynamic equilibrium as it was conceived by Austrian economists, most notably Schumpeter (1939), who introduced the idea of trajectories in his history of economic analysis.

- A shift towards a demand, value-based driven (Friedman, 2006) understanding of destination economics .

- A way to incorporate heterogeneous demand, even individual visitor's demand into the existing analytical framework of economics.

\section{Molecular treatment}

Ingredient 1: Treatment of spaces and knowledge as atoms and molecules

The economic success of destinations involves the right use and augmentation of geographical resources. This blending of tourism spaces with economic spaces seems to occur at the point of knowledge creation and consumption (Jafari, 2001; Pine and Gilmore, 1999; Arthur, 1994a; Culler, 1981) and its operationalization in the form of institutions, rules and behavioral heuristics (Zipf, 1949; Hayek, 1964; Gibson, 1979; Ridley, 1998; Turner and Penn, 2002). Taken as such, geonomic space and economic spaces both share an intersection with knowledge creation. Despite past efforts to incorporate spatial aspects into the existing neoclassical dogma (see for example, Eaton and Lipsey, 1976) and recent advances in knowledge economics; a suitable construct, merging space and knowledge, is still missing from the neoclassical literature

Not only is the problem one of a lack of appropriate constructs, it is also one of bridging theoretical and inter-disciplinary chasms. Much of the economic efforts have only seen a progress on either the spatial or knowledge front - not on both the spatial and knowledge fronts simultaneously. Tourism economists have given emphasis to the supply-side of economic spaces, while tourism researchers 
seem to be enthralled with the demand-side of geonomic spaces.

Meaningful destination experiences can be understood as a knowledge-creating problem (Moscardo, 1996). Such an orientation has traditionally been in the domain of tourism researchers (Pearce, 1999), marketers (Plog, 1973) and sociologists (Urry, 2002) who emphasized the experiential aspects of place, in destinations. At a more generic level, these are complemented by growing interests in what has been termed the experience economy (Pine and Gilmore, 1999). In our context these discussions constitutes advances in the knowledge-based conceptions of destinations apart from its obvious spatial character.

Not only does destination analysis lack the blending between the geonomic spaces and economic spaces but it is also plagued by the problem of scaling to higher or lower order space (Samat 2006; Bualhamam 2009). Nevertheless, notable attempts have been made at connecting space at different hierarchical levels (Anas, Arnott and Small, 1998). Plog's (1973, 2001) conception of destination evolution is particularly useful in providing a framework for destination scalingups from the level of the visitor. The scaling up process involves determining the personality characteristics of travelers and then inferring the mobility patterns based on a matching between personality characteristics and destination characteristics (Girardin, Vaccari and Ratti, 2008). There are two extreme visitor types corresponding to destination extreme types: allocentrics and psychocentrics. In a 2001 update (Plog, 2001) to his 1973 article, Plog called allocentrics: venturers; and psychocentrics: conservatives. But we shall revert to the older terms of: allocentrics and psychocentrics; because they are more explicit in bringing out the psychological characterizations of destinations.

Allocentrics, as a group of tourists, are engaged more directly in their tourism experiences, proactively creating their tourism experiences. Psychocentrics on the other hand are the exact opposites of allocentrics. They are likely to be mass consumers of packaged tourism, preferring to stick to tried- and-tested offers. Plog (2001, pg. 15) offers three major personality characteristics upon which to operationalize the two psychographic extremes. They are: generalized anxieties, sense of powerlessness and territory boundedness. Psychocentrics were plaqued by low-level feeling of anxieties, they take a reactionary stance to life build around fate, and they make little attempts throughout their lives to expand their geographical horizons. Allocentrics in contrast, tend to register much lower levels of personal anxiety, they consciously make decisions, taking the necessary risks and are significantly more curious with more varied interests. This partially explains the higher incidences of exploratory travel.

Translated to our present spatial-knowledge context, we could hypothesize that psychocentrics would be more tolerant of homogenous knowledge reflected in spatial homogeneity, spatial contiguity and psychological proximity. In contrast, allocentrics value randomized events, fresh and new knowledge, which is often reflected in fragmented and more individualized space. Consequently destinations tend to have, mirrored in them, these spatial characteristics, which is a scaling up from the personality characteristics of their visitors.

From a policy perspective, positioning of destinations require knowledge about destination lifecycles and the psychographic forces influencing their evolution over the lifecycle. For Plog, the fact that most destinations go through the typical S-curve lifecycle (Butler, 1980) is a well-accepted idea, however the onus lies with planners in having to recognize the psychographic mechanics behind a destination's evolution and to manage accordingly or otherwise to re-position the destination.

Plog is very much against the fatalistic approach that was prevalent even at the time of his review of the state-of-the-art (Plog, 2001), where he reports that the initiatives at many destinations are more of a reaction to the demands that present themselves at each stage. He cautions against such reactive policies and argues for a proactive approach 
involving the management of different visitor types, and always in so doing to bear in mind the co-evolution that involves visitors and destinations.

The direction of influence between visitors is a vital component in Plog's theory because it holds the key to understanding how destinations and visitors co-evolve. The direction of influence is from the allocentrics to the psychocentrics. Correspondingly, at the initial phases of a destination's lifecycle, the destination is populated mainly by allocentrics, they were the ones who 'discovered' the exotic gem of a place. Consequently, the psychocentrics were introduced to these destinations by the allocentrics. During the maturity phase and onwards psychocentrics begin to be the dominant category of visitors.

Since the increased frequency of arrivals of psychocentrics and their dominant presence at a destination tends to precipitate the decline of a destination, Plog $(1973,2001)$ focuses much of his discussions on strategies aimed at keeping destinations fresh and interesting for allocentrics.

Ingredient 2: The right configuration in the molecules is given by the level of spatial complexity observed

The complexity approach in the modeling of destination evolution is made much simpler if we could focus on observed complexity. We have chosen tourism space as our unit of analysis. The spatial complexity of destinations can be reduced into its density and diversity components. Our treatment of density and diversity in space is drawn from the literature in spatial economics and urban economics (von Thunen, 1826; Hotelling, 1929; Losch, 1940; Alonso, 1964). In particular we refer to the recent, more generalized (Martin and Sunley, 1996) version of location theory based on international trade theory and imperfect competition (Dixit and Stiglitz, 1977), also known as The New Economic Geography (NEG). Though the scope of research is mainly cities we could draw similar conclusions to destinations.
In the NEG, cost is closely related to spatial density. Proponents of NEG treat cities as trading centers; being strongly influenced by international trade theory (Martin and Sunley, 1996) that underpins much of the explanations on the origin, size and distribution of cities (Krugman 1991a). Furthermore cities are, among other things, a result of: planning, expectations, self-reinforcing forces, a priori factors, increasing returns (Arthur, 1994a) and economies of scale. The number and size of cities (destinations) are a function of two opposing forces: centripetal (i.e. agglomeration) forces and centrifugal (i.e. deagglomeration forces). Spatial equilibrium is achieved at the balance between these two opposing forces (Krugman 1991a). Cities are the product of spatial economic organization resulting from such an interaction. Such a conception is analogous to markets, which is the product of the forces of demand and supply. Centripetal forces, the force that keeps cities together are themselves a function of transportation costs and increasing returns. The foremost economic function of cities, and by analogy destinations, is thus to maximize resource efficiency as it relates to space. Most notably: land and labor.

While spatial density provides the necessary conditions for agglomeration, spatial diversity completes the competitiveness imperative. Destinations exists to maximize the utility of visitors by providing a wider, more diversified range goods with differentiated at closer proximities (Papatheodorou, 2001). In other words, the sweet spot on a destination's lifecycle involves a balance between the level of travel and the quality of experience (Plog, 2001, pg. 23). Incidentally there is a supply counterpart to these fundamental demandoriented conditions. On the supply side, a destination's continued attractiveness is dependent upon its authenticity, which in turn is a function of a destination's true qualities and its perception amongst tourists (Plog, 2001, pg. 20). Putting supply and demand aspects together we derive two pairs of spatially related conditions. The first pair is connected to the spatial density of tourism activities, involving: the level of travel and the true, observable qualities of a destination. The second pairing of conditions is related to spatial diversity, they 
are the: quality of tourism experience and the perception of tourists about a destination. Hence the relative significance of spatial density and diversity provides for us a yardstick to gauge competitiveness and sustainability of destinations.

Ingredient 3: the molecular configurations exhibit complexity during a transitory phase known as the edge of chaos (Langton, 1990).

Dopfer and Potts (2008) conception of economic evolution as the evolution of generic rules allows us to assess the competitiveness of destinations based on the idea of rule complexity. Rules underlie economic evolution and more specifically destinations. To begin our systematic analysis of rule evolution it would be useful to use the following organizing scheme from Klein (1997) of: spontaneous order (catallaxy) and emergent rules (convention). Praxis is said to be process connecting the two, catallaxy and convention. Praxis or the transitory phase, which Dopfer and Potts (2008) calls the meso domain, is largely shrouded by complexity and treated as a black box. Nevertheless, as a concept it coincides very closely to the idea of an edge of chaos (Langton 1990).

Catallaxy is a distinctly Austrian notion, due to Hayek (1964), that describes the emergent market order, that though imperceptible to our senses, is nevertheless traceable by our intellect. This is analogous to our macro-level understanding of destination structure. We could say that the "invisible hand" (Smith, 1776 ) is the process by which such a catallaxy comes into being. But it is evident that such an "invisible hand" operates through emergent rules that come about through a process of coordination very similar to seating arrangements problems typified by Schelling (1978) and the El Farol bar problem (Arthur, 1994b). At the macro level, the spontaneous undesigned economic order (Menger, 1883; Schumpeter, 1934; Hayek, 1964) is a cumulative state derived from interactions occurring mainly at the micro-level. The meso level is characterized by the transformation of individual rules that in turn originate from practice at the micro level or interactions, which is central to Menger's idea of praxis. The next

section details the dynamics of destination evolution based on the idea of molecule reconfiguration as a contagion process.

\section{Methodology \\ Destination evolution as a knowledge contagion}

Plog's model is implemented as an excitable media. The fundamental unit in the media, individual cells representing the visitor, goes through a excited-refractory-quiescent cycle (Gaylord and Nishidate, 1996:156-158) which we assume corresponds roughly to allocentricmixed (allocentric/psychocentric)-nontourist categories in Plog's psychographic curve.

To generate the simulated data we employ a transition function that describes the bottom-up process that results from the interaction between spatial entities. Referring to Couclelis (1988)'s formulation, the state of a onedimensional cellular automaton (CA) at time $t$ : $a_{i}^{(t)}$, is given by the following iterative mapping:

$\mathrm{a}_{\mathrm{i}}{ }^{(t)}=F\left(\mathrm{a}_{\mathrm{i}-\mathrm{r}}{ }^{(t-1)}, \mathrm{a}_{\mathrm{i}-\mathrm{r}+1}{ }^{(t-1)}, \ldots, \mathrm{a}_{\mathrm{i}}{ }^{(t-1)}, \ldots, \mathrm{a}_{\mathrm{i}+\mathrm{r}}{ }^{(t-1)}\right)$

Where $F$ are transition functions governing the changes in the states of cells from one time period to another. The parameter, $r$ specifies the range of the neighborhood of the automaton. Varying the $r$ values allows us to distinguish one spatial scale from another. For instance, $r=9$ may represent the spatial scale at the attraction context, $r=15$ at the regional context and so on. $t$ is in terms of discrete incremental steps. Higher values for $r$ would mean that it takes more $t$ increments before we observe changes to $a_{i}^{(t)}$. $a_{i}^{(t)}$ would be constrained to take the values within the range: 0 to 2; corresponding to three cell states. Mapping Equation (1) to three possible generic cell states we have the following scheme, representing the range of spatial diversity in the simulation:

$$
\begin{aligned}
& a_{i}^{(t)}=0 \rightarrow \text { non-tourism } \\
& \text { states } \\
& \mathrm{a}_{\mathrm{i}}^{(t)}=1 \rightarrow \text { tourism state \#1 } \\
& \text { (allocentricity) } \\
& a_{i}{ }^{(t)}=2 \rightarrow \text { tourism state \#2 } \\
& \text { (psychocentricity) }
\end{aligned}
$$


Our 2D exitable media model of destinations is parameterized as follows in MATHEMATICA:

$$
\text { contagion[n_, s_, a_,g_,t]:= }
$$

Module[\{population, spread, vonNeumann\}

Some details on the parameters of the simulated destination system:

- $\quad \mathrm{n}$ : population size, given by the lattice size

- a: number of allocentrics (e.g. those already infected)

- g: refractory time ( time decay for allocentricity)

- $\mathrm{s}$ : spread $=$ the infectiousness of allocentrics

- $\quad t:$ number of iterations in the simulation

- vonNeumann: the spatial character of the tourist's neighborhood, provides a means for us to scale the context (i.e. attraction, regional, global)

\section{Findings}

The patterns in Figure 1 are 6 snapshots of an exploratory run in our model simulation. These $2 \mathrm{D}$ visual patterns can be thought of as topdown snapshots, aerial views of a crowded attraction area. The array of snapshots, starting with the left hand side of the $1^{\text {st }}$ row and moving into the left hand side of the $2^{\text {nd }}$ rows corresponds to iterations: $t=1, t=5, t=10, t=18$, $t=50, t=79$ for a lattice size of measuring $50 X$ 50 in dimension. This translates to a total population of 2500 entities (tourist and nontourist combined at any given iteration). Assuming that the grey scale visuals represent varying levels of psycho-graphical orientations, a continuum spanning from non-tourists to psychocentrics to allocentrics (white to grey to black), a phenomenological study of the patterns permits the following inferences:

\section{Molecular information-rule origination}

a) Spatial Structure: Allocentrics originated the rules that will play out in the latter iterations. The initial clusters were predominantly allocentrics, as the case with $t=5$. The spread of the cluster and the growth of density was spurred on by the allocentrics reaching a maximum effect at $t=10$. It could be said that the allocentrics solidified the spatial form of the destination by around $t=18$, the spatial structure of the region had stabilized and the remaining time frames were characterized by variations in the density of allocentrics versus psychocentrics. Higher levels of diversity begin to be build into the system until it was overwhelmed by the psychocentrics at $t=79$. Where henceforth up to $t=100$ the system was $100 \%$ psychocentric.

b) Spatial Character: It is evident from $t=5$ onwards that the area took on a more touristic feel when some densities and clustering began to emerge. Prior to that at around $t=1$, the area was just a randomized collection of entities spanning the spectrum of tourists and nontourists. The self-organizing process at destinations were spearheaded by the allocentrics as evidenced by the darker regions around the edges of clusters formed at $t=5$. We also witness an increasing number of clusters starting from $t=1$ to $t=10$. In the context of Plog's theory it would represent the number of entities in space that are increasingly tourismmotivated. Resulting in tourist hotspots and clusters that are quite distinctive by $t=10$. These hotspots take after the character of their constituent tourists. It is interesting to note that even though around $t=5$, the clusters were mainly psychocentric, by around $t=10$ they have become predominantly allocentric in character.

\section{Molecular interchange/edge of chaos-rule adoption}

a) Co-evolution. Reversals are possible and seem to play a role in keeping the destination sustainable. The simulation shows that an already allocentrically-distinct destination $(t=10)$ can, through time, become more mixed $(t=18)$ and in effect become less allocentricallydominant. In effect becoming more spatially diversified given more time. The diversification is at the level of tourists' variety (i.e. psychographic profiles) and spatial forms.

b) Sweet Spots. Comparatively $\mathrm{t}=10$ is less tourist-intensive (lower density of tourists- non white cells) compared to $t=18$, but the distinct character of the hotspots were more scaledriven (at $t=10$ ), with higher intensities of allocentrics relative to psychocentrics. By contrast, $t=18$ is more tourist-intensive, with a 


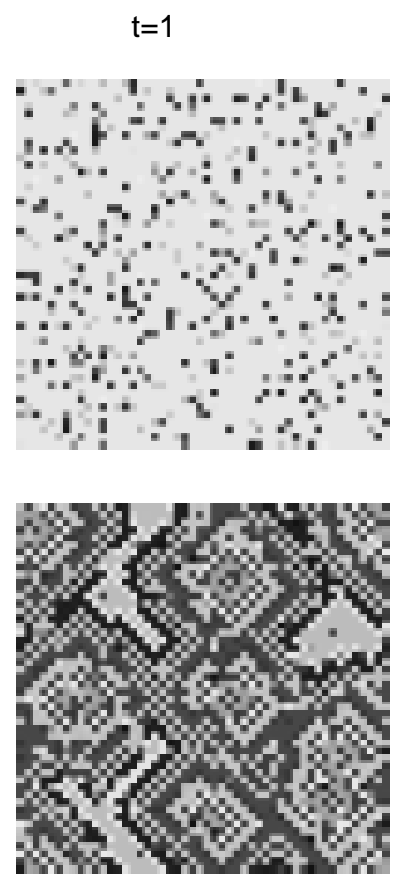

$t=18$
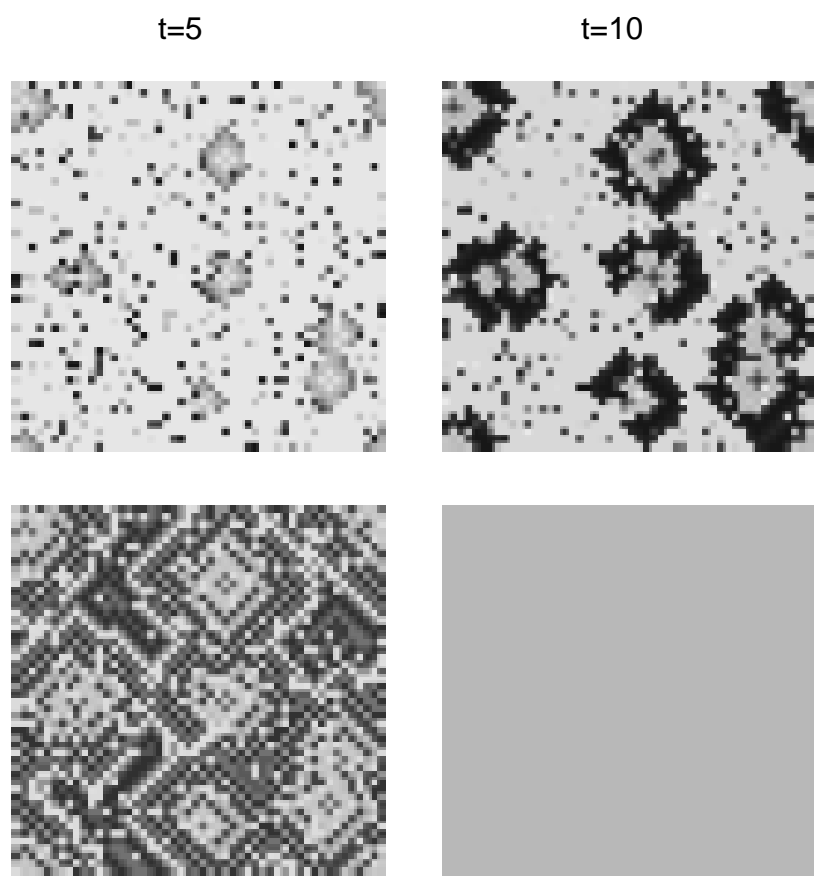

$t=50$

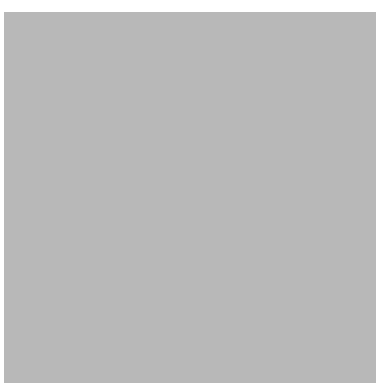

$t=79$

Figure 1. Exploratory run of a crowded attraction simulation of destination evolution

mix of psychocentrics and allocentrics. Though scale had some role in this, this phase shows comparatively more diversity in scope and spatial form around $\mathrm{t}=18$ as compared to $\mathrm{t}=10$.

\section{Molecular fusion-rule retention}

a) Capacity limits. During a certain phase represented by the snapshot, $t=10$, the character of the destination was quite distinct from that of the other phases. The tourist hotspots were mostly allocentric-intensive around $t=10$. It could be said that the allocentricity capacity limit was reached around $t=10$. Allocentric rules have reached their rule retention phase. The macro structure of the destination mimics that of its underlying micromotives. The capacity limits sets an upper bound to the destination evolution.

b) Planning: sensitivity to initial conditions. A destination initially populated with a random mix of psychocentrics and allocentrics (as is the case with $t=1$ ) eventually reach stasis at around $t=79$. The steady state that was achieved at $t=79$ coincides with Plog's conjecture that a destination will mature when most of its tourist are psychocentrics. In this prototypical example, one would not have been able to deduce from the randomized initial settings what the eventual state of the system would be. Reinforcing the again the need for simulations to flesh out how stasis and final outcomes are achieved in a destination's evolution. One suspects that in less randomized occasions it may be quite significant even though Plog seems to postulate that the stasis point should coincide with a tourist trap- which results at $t=79$ seems to suggest. This would be investigated in the other experiments that follow. The sensitivity to initial condition forces us to consider the critical, necessary conditions conducive to destination competitiveness.

c) History and expectations (Krugman, 1991a): trajectory and self-organized criticality (Bak, Tang and Wiesenfeld, 1987). The endogenous process of self-organized criticality precipitated the destabilization of the destination system 
that led to a situation that is less allocentricallymotivated. The trajectory of a system cannot be predicted in advance, it began to play out as the system evolved. As stated in the context of destination development: a destination may not be predestined to end up as expected. Neither is the process smooth but may instead exhibit disruptions and upheavals. This is the essence of self-organized critically; a system reinforces itself until a destabilization happens that brings it to a new evolutionary path (Bak, et.al, 1987). That such situations can arise in a closed system should not be surprising. As attested by the experiment: except for the initial randomized starting point, the system evolved deterministically after $t=1$ without any external perturbations. However later in it evolutionary path it experience a destabilization and collapsed into a state that showed no diversity but was $100 \%$ dense and $100 \%$ homogenous with respect to psychographic profiles (nearing the psychocentric end of the psychographic spectrum).

\section{Cases}

We started the paper by arguing that current developments necessitate a shift towards atomistic approaches in our economic analysis of destinations. In stressing the merits of a research program centered on methodological individualism and the critical role of tourists, we are not suggesting that the supply-side, infrastructure challenges are negligible. Rather as we shall see in the case of Singapore and Venice, the seeming dilemma between planning and organic growth quickly disintegrates when we realize that molecular metaphors function more as analytical apparatuses (Mitchell, 1993), complementing real world interventions and policies that must necessarily be top-down in its approach. While our primary mode of investigation were computer simulations in the preceding section, Singapore and Venice are two extreme "realworld simulations" corresponding crudely to $\mathrm{t}=5$ and $t=50$ in Figure 1, respectively.

\section{Singapore}

Singapore, like many cities of the world, has a historic core (Borg, Costa and Gotti, 1996; Canestrelli and Costa, 1991) that can be developed strategically as a tourism product. Tourism planning, in this sense, pre-conditions expectations or reinforces it. Since as a whole, Singapore is a relatively young cosmopolitan city, we can locate its destination evolution in the rule origination phase.

This historic heritage in Singapore, are in some ways very closely-linked to other cities in the region. For example, most cities in ASEAN countries have an underlying South Asian cultural character and build heritage. Still there are aspects to its cultural heritage that lends it a unique individuality. For its unique historic attractions function as placement points upon which the full molecular structure of its destinations will unfold as time goes by. Given these emergent features, and the relativity of tourists' gaze (Urry 2002), planning and interventionist policies become essential for strategic tourism development. It is all about starting well. Imperfect competition arising from slight subtle differences among Asian heritage cities makes strategic planning an imperative for destination branding (Askew and Logan, 1994).

However at times, the sustainability of heritage sites becomes a function of expectations (Krugman, 1991b). Once a threshold is reached, globalization and other developments can quickly invalidate our plans and necessitated a more emergent, bottom-up response. Example, evolving expectations have given rise to efforts at preserving the indigenous identity of Singapore through urban conservation (Keys, 1981) while simultaneously pursuing the goal of becoming a global city. We see the co-influence of history and expectation in this situation. The challenge is to maintain a correct balance at the cusp between planning and expectations. It is very important to cultivate a flexible stance in the midst of a regimented approach. In fact there are indications that a more organic approach may be beneficial. A departure from Singapore's planning predilections may be the muchneeded breath of fresh air. Tourists who visit cities like Singapore, especially those on tour packages, are essentially intermediate tourism goods - their final tourism experiences do not necessarily begin or end at a particular city (Britton, 1991). The whole urban tourism experience is a flow of images and memories that is either enhanced or destroyed between 
city visits (Meethan, 1996). It would be a mistake to leave tourists with an impression that their experience was engineered rather than serendipitous (Yuen 2005), and in so doing destroy the mystique that is Singapore.

\section{Venice}

As a tourist historic city, Venice is an extreme contrast to Singapore. One would locate it at the rule retention phase of a destination's evolutionary path. Its history has played a major role in the formation of its current spatial character. Organic growth and expectations has driven it to the point where planning becomes crucial for its success as a tourist city. Whereas the issue with Singapore is its weak place identity (Yuen, 2005), Venice has to manage the immense flow of tourist due to it mature historical core that has been forged through hundreds of years of urban conservations. Ironically the very urban environment hat has been a major tourist draw, has itself fallen prey to the dictates of tourist demand. For example, the carrying capacity at Saint Mark's Basilica is frequently exceeded (Canestrelli and Costa, 1991). Such selforganizing processes can turn vicious. Ideas such as: lock-in, the trap of primacy and selffulfilling prophecies help to explain why vicious cycles may be operation in Venice (van der Borg, Costa and Gotti, 1996).

Having reached the molecular fusion phase of a capacity limit, Venice hopes that innovative planning initiatives will break the vicious cycle of "tourisfication" (Meethan, 1996). The commodification (Shaw and Williams, 2004) of Venice's urban heritage has created a dual identity. The image that is presented to most tourist of Venice is in stark contrast to the Venice that local residents are familiar with. Excursionist and day-trippers have crowded out the locals' use of such amenities public places and the transport system. The permanent population of Venice has fallen while the tourist volume has increased tremendously.

With the "tourisfication" of Venice Main Island underway comes a corresponding displacement of its native population to the surrounding region and a change of its retail structure to reflect the touristy feel that it has come into (Zanini, Lando and Bellio, 2008).
This trend, though disadvantageous to Venice locally, has been beneficial to the regions surrounding it. Especially the mainland regions and islands belonging to the Vento province. In other words, the molecular fusion has reached a criticality and disruptions and upheaval will ensue. These external economies indicate that Venice, as a tourist city, has a tremendous range and high demand threshold. Thus just like the ripple effect observed in our simulation of destination evolution, the agglomeration effects expands outwards from the nucleus that is Venice in the form of secondary tourism developments in other parts of the Venetian lagoon.

\section{Conclusions}

In our discussions we addressed the dilemma of planning and expectations, pointing the way to successful destination development through insights obtained from a simulation of molecular tourism. Destination evolution was conceived as an unraveling of a destination's molecular structure, which in essence contains the following ingredients:

\section{$\checkmark$ Ingredient 1: Treatment of spaces and knowledge as atoms and molecules. \\ $\checkmark$ Ingredient 2: The right configuration in the molecules is given by the level of spatial complexity observed. \\ $\checkmark$ Ingredient 3: the molecular configurations exhibit complexity during a transitory phase known as the edge of chaos.}

The conceptualization was followed by a simulation of the molecular structure and dynamics of destinations, demonstrating destination emergence as a spatial contagion of knowledge. For which the methodology:

$\checkmark$ Characterized tourism experiences as molecular interactions, converting what is usually regarded as a flow experience into discrete packets of space.

$\checkmark$ Adopted Plog's co-evolutionary model of destination development allowing for bottom-up scaling that seamlessly ties individual visitors to emergent destinations.

$\checkmark$ Appraise the successfulness of destinations based on a dynamic equilibrium as conceived by Austrian economists such as Schumpeter (1939). Most notably using the notion of 
destination trajectories in our economic analyses.

Our exploratory simulations and conjectures on cases of heritage tourism led us to believe that the target and emphasis of policy makers should be on the rule adoption phase (edge of chaos) and not rule origination (creativity) or rule retention (conservation) per se. This is the case since both rule origination and retention are very much givens. Individuals serve as originator of the knowledge code, this knowledge eventual manifest itself in the spatial configurations of destinations. Rule retention, is the phase were the knowledge transfers have been stabilized; being the outcome of massively parallel interactions involving the interaction of rules.

It would seem therefore that, as is the case with Singapore, planning to address insufficient demand should be complemented by room for more organic growth. Such an organic approach necessitates flexibility and agility in dealing with extraneous factors. Where else with overwhelming demand, as is the case with Venice, supply and capacity bottlenecks need to be rein in by an all-inclusive plan (Borg, Costa and Gotti, 1996).

Therefore to summarize our molecular treatment of destinations, the following guidelines are stressed:

$\checkmark$ A shift towards a demand, value-based conception of destination economics

$\checkmark$ A way to incorporate heterogeneous demand, even individual visitor's demand into the existing analytical framework of economics. $\checkmark$ Seek to re-center and incorporate individual perceptions in arriving at destination image assessments.

Hence the ideal is one where destination image formation is properly understood as an emergent property, running in parallel with destination management. We cannot begin to properly formulate top-down responses to destination challenges without a prior knowledge of bottom up dynamics. This is the dominant paradigm in the natural sciences and is likely to be the next paradigm shift in destination research: "the scientification of tourism" (Jafari, 2001).

\section{References}

Akerlof, G. A. \& Shiller, R. (2011). Animal spirits: how human psychology drives the economy and why it matters for global capitalism. Princeton University Press.

Alonso, W. (1964). Location and land use. Cambridge, MA: Harvard University Press.

Anas. A., Arnott, R. \& Small, K. A. (1998). Urban spatial structure, Journal of Economic Literature, 36(3),1426-1464.

Arthur, B. W. (1994a). Increasing returns and path dependence in the economy. Ann Arbor: The University of Michigan Press.

Arthur, B. W. (1994b). Inductive reasoning and bounded rationality (The El Farol problem). American Economic Review (Papers and Proceedings), 84(2), 406411.

Askew, M. \& Logan, W. S. (1994). Cultural identity and urban change in Southeast Asia: interpretative essays. Geelong: Deakin University Press.

Bak, P., Tang, C., \& Wiesenfeld, K. (1987). Selforganized criticality. Physical Review Letters, 59, 381-387.

Bualhamam, M. R. (2009). The study of urban growth impact in tourism area using remote sensing and GIS technique for north part of the UAE. Journal of Geography and Regional Planning, 2(6), 166-175.

Butler, R. W. (1980). The concept of a tourist area cycle of evolution: implications for management of resources. Canadian Geographer, 24(1), 5-12.

Canestrelli, E., \& Costa, P. (1991). Tourist carrying capacity: A fuzzy approach. Annals of Tourism Research, 18(2), 295311.

Couclelis, H. (1988). Of mice and men: what rodent populations can teach us about complex spatial dynamics. Environment and Planning $A, 20(1)$, 99-109.

Culler, J. (1981). Semiotics of tourism. American Journal of Semiotics, 1(1-2), 127-140.

Dixit, A. \& Stiglitz, J. E. (1977). Monopolistic competition and optimal product variety. American Economic Review, 67(3), 297308.

Dopfer, K. \& Potts, J. (2008). The general theory of economic evolution. Cornwall: Routledge. 
Eaton, B. C. \& Lipsey, R. G. (1976). The Introduction of Space into the Neoclassical Model of Value Theory. Discussion paper, Institute for Economic Research, Queen's University, No. 239.

Friedman, T. L. (2006). The world is flat: a brief history of the $21^{\text {st }}$ century. New York, NY: Farrar, Straus and Giroux. $2^{\text {nd }}$ ed.

Gaylord, R, \& Nishidate, K. (1996). Modeling nature: cellular automata simulations with Mathematica, TELOS. Springer Verlag.

Gibson, J. J. (1979). The ecological approach to visual perception, Boston, MA: Houghton Mifflin.

Girardin, F., Vaccari, A. \& Ratti, C. (2008). Uncovering the presence and movements of tourist from user-generated content. Paper presented at 9th International Forum on Tourism Statistics, Paris, France.

Goodspeed, T. B. (2012). Rethinking the Keynesian revolution. Oxford University Press.

Hayek, F. A. (1964).Kinds of order in society, New Individualist Review, 3(2), 3-12.

Iso-Ahola, S. E. (1982). Toward a social psychological theory of tourism motivation: A rejoinder. Annals of Tourism Research, 9(2), 256-262.

Ivanov, S. H., Illum, S. F. \& Liang, Y. (2010). Application of destination brand molecule on destination image and brand perception: an exploratory study. Tourism, 58(4), 339-360.

Jafari, J. (2001) The scientification of tourism. In V. Smith \& M. Brent (eds.) Hosts and guests revisited: Tourism issues of the 21st century. New York: Cognizant Communication Corporation. pp. 28-41.

Kahneman, D. (2011). Thinking, fast and slow. Farrar, Straus \& Giroux.

Kahneman, D. \& Krueger, A. B. (2006). Developments in the measurement of subjective well-being. Journal of Economic Perspectives, 20(1), 3-24.

Keys, P. (1981). Conservation as an integral part of urban renewal. Planews: Journal of the Singapore Institute of Planners, 8, 39-49.

Klein, D. B. (1997). Convention, social order and the two coordinations. Constitutional Political Economy, 8, 319-335.

Krugman, P. (1991a). History versus expectations. Quarterly Journal of Economics, 106(2), 651-668.
Krugman, P. (1991b). Increasing returns and economic geography. Journal of Political Economy, 99, 483-499.

Langton, C. G. (1990). Computation at the edge of chaos: phase transitions and emergent computation. Physica D, 42, 12-37.

Lederer, C \& Hill, S. (2001). See your brands through your customers' eyes. Harvard Business Review, 79(6), 125-133.

Lösch, A. (1940, in translation 1954). The economics of location. New Haven, CT: Yale University Press.

MacCannell, D. (1976). The tourist: a new theory of the leisure class. New York: Schocken Books.

Martin, R. \& Sunley, P. (1996). Paul Krugman's geographical economics and its implications for regional development theory: a critical assessment. Economic Geography, 72(3), 259-292.

McKercher, B. \& Lau, G. (2008). Movement patterns of tourists within a destination. Tourism Geographies, 10(3), 355-374.

Meethan, K. (1996). Consuming (in) the civilized city. Annals of Tourism Research, 23(2), 322-340.

Menger, C. (1883[1985]). Investigations into the method of the social sciences with reference to economics. [Edited by Louis Schneider, with a new introduction Lawrence H. White]. New York: New York University Press.

Mises, Ludwig von. (1962). The ultimate foundation of economic science. Princeton: Van Nostrand.

Mitchell, M. (1993). Analogy-making as perception: a computer model. Cambridge: MIT Press.

Moscardo,G. (1996). Mindful visitors, Annals of Tourism Research, 23: 376-397.

Papatheodorou, A. (2001). Why people travel to different places. Annals of Tourism Research, 28 (1): 164-179.

Papatheodorou, A. (2003). Modelling tourism development: a synthetic approach. Tourism Economics, 9 (4): 407-430.

Parker, W. D. and Prechter, R.R. (2005). Herding: An Interdisciplinary Integrative Review from a Socionomic Perspective. International Conference on Cognitive Economics. Sofia, Bulgaria. August 5-8, 2005.

Pearce, D.G. (1999). Tourism in Paris: studies at the microscale, Annals of Tourism Research, 26 (1):77-97. 
Perroux, F. (1950). Economic space: theory and applications. The Quarterly Journal of Economics, 64(1): 89-104

Pine, B.J. and Gilmore, J.H. (1999). The experience economy: work is theatre and every business is a stage. Boston Mass: HBS Press.

Plog, S.C. (1973). Why destination areas rise and fall in popularity. Cornell Hotel, Restaurant and Administration Quarterly, 14(4), 55-58.

Plog, S.C. (2001). Why destination areas rise and fall in popularity: an update of a Cornell quarterly classic. Cornell Hotel, Restaurant and Administration Quarterly, 42(3), 13-24.

Polanyi, M. (1958). Personal knowledge: towards a post-critical philosophy. London: Routledge and Kegan Paul.

Pred, A. R. (1966). The spatial dynamics of U.S. urban-industrial growth, 1800-1914: interpretive and theoretical essays. Cambridge, MA: MIT press.

Prechter, R. R. (2003). Pioneering studies in Socionomics. Gainsville, GA: New Classics Library.

Ridley, M. (1998). The origin of virtue: human instincts and the evolution of cooperation. Penguin.

Ritchie, J. R. B \& Zins, M. (1978). Culture as a determinant of attractiveness of a tourist region. Annals of Tourism Research, 5(2), 252-267.

Ritchie, J. R. B. \& Crouch, G. I. (2003). The competitive destination: a sustainable tourism perspective. Wallingford, Oxon: CABI Publishing

Samat, N. (2006). Characterizing the scale sensitivity of the cellular automata simulated urban growth: a case study of the Seberang Perai Region, Penang State, Malaysia. Computers, Environment and Urban Systems, 30(6), 905-920.

Schelling, T. C. (1978). Micromotives and Macrobehavior. W. W. Norton \& Company

Schumpeter, J. A. (1908[1980]). Methodo-logical individualism. Brussels: Institutum Europæum. [ English translation by
Michiel van Notten of the corresponding chapter of Joseph Schumpeter (1908) Das Wesen und der Hauptinhalt der theoretischen Nationalökonomie, with a preface by F. A. Hayek, and a Summary by Frank van Dun].

Schumpeter, J. A. (1912 [1934]). The theory of economic development. Oxford: Galaxy Books.

Schumpeter, J.A. (1939). Business cycles: $A$ theoretical, historical and statistical analysis of the capitalist process. New York: McGraw-Hill.

Shaw, G. \& Williams, A.M. (2004) Tourism and tourism spaces. London:Sage.

Smith, A. (1937[1776]) The wealth of nations. Edited by Edwin Cannan. New York: Modern Library.

Smith, S. L. J. (1994). The tourism product. Annals of Tourism Research, 21(3), 582595.

Turner, A. \& Penn, A. (2002). Encoding natural movement as an agent-based system: an investigation into human pedestrian behaviour in the built environment. Environment and Planning B: Planning and Design, 29(4), 473-490.

Urry, J. (2002). The tourist gaze. Sage Publications.

Urry, J. (2005). The complexity turn. Theory, Culture \& Society, 22(5), 1-14.

van der Borg, J., Costa, P. \& Gotti, G. (1996). Tourism in European heritage cities. Annals of Tourism Research, 23(2), 306321

van der Linden, E., McClements, D. J. \& Ubbink, $\mathrm{J}$ (2008). Molecular gastronomy: a fad or interface for science-based cooking? Food Biophysics, 3(2), 246-254.

Veblen, T. B. (1899). The theory of the leisure class. An economic study of institutions. London: Macmillan Publishers.

von Thünen, J. (1826). The Isolated state. English edition, London: Pergamon.

Yuen, B. (2005). Searching for place identity in Singapore. Habitat International, 29(2), 197-214.

Zipf, G. K. (1949). Human behavior and the principle of least effort. Reading: Addison-Wesley. 